\title{
2 The Hungarian Experience of Using Cohesion Policy Funds and Prospects
}

\author{
Györgyi Nyikos ${ }^{42}$ \& Gábor Soós ${ }^{43}$
}

\begin{abstract}
Since Hungary joined the European Union, cohesion policy funds have opened up a number of opportunities for development. The general belief was that, with such funding, the prospect of higher economic growth, new jobs, higher wages and improved standards of living would arrive. While Hungary has implemented a number of projects, and the country has been fairly successful in the absorption of funds, there has not been a real sentiment of success following the closure of the last two programming periods. Despite being one of the biggest net beneficiaries of funds, Hungary has not achieved exceptional economic performance. In light of this, it is important to examine the possible causes of this limited success. This research thus presents an overview of the evolution of the administration dealing with cohesion policy and the set-up of the legislative framework in each programming period. Data analysis is conducted on Hungary's use of EU funds and is contrasted against economic indicators during the same period. Based on the findings from analysing Hungary's prospects as a recipient of EU funds, suggestions are made about what the implementation practice should take into consideration.
\end{abstract}

Keywords: Cohesion policy, development fund's effects, institution system, simplification

\subsection{Introduction}

A review of literature revealed a lack of consensus on whether or not cohesion policy has a true impact on the economic performance of EU member states. In some studies, research carrying out in-depth analysis on this subject evidenced significant impact. In the 90s, several studies measured impact using macroeconomic models (e.g. Cappelen et al., 2003; Pereira \& Gaspar, 1999). The European Commission has published plenty of evaluation studies ${ }^{44}$, where findings broadly confirmed the positive impact of subsidies. There is also a body of literature indicating that EU cohesion policy does not result in the desired impact on Central and Eastern European

42 National University of Public Service, Institute of Public Finance and Financial Law, Hungary. Correspondence: nyikos.gyorgyi@uni-nke.hu

43 National University of Public Service, Institute of Public Finance and Financial Law, Hungary.

44 Please visit http://ec.europa.eu/regional_policy/en/policy/evaluations/

Ә Open Access. (c) 2020 Ida Musiałkowska, Piotr Idczak, Oto Potluka and chapters' contributors. Published by De Gruyter. (c) BY-NC-ND This work is licensed under the Creative Commons Attribution-NonCommercial-NoDerivs 3.0 License. https://doi.org/10.1515/9788395720451-007 
(CEE) countries. Borsi and Metiu (2013) have concluded that there is no real income per capita convergence in the European Union (Borsi \& Metiu, 2013: 11). Others have pointed out that the convergence process has been interrupted by the economic crisis and that disparities will prevail, not only between the old and new member states, but also between the richer and poorer regions. The sluggish pace of the convergence process will be insufficient to counterbalance the forecasted increase in disparities (Camagni \& Capello, 2014: 7).

A simple examination of Hungarian data from the past 12 years does not capture the impact of the funds received. ${ }^{45}$ In fact, the Hungarian economy has struggled in various ways as early as 2007 , and only started to recover fully from the economic crisis in recent years. Nevertheless the main objective of cohesion policy-namely, to help convergence-in CEE countries might not be immediately obvious from basic economic data. The data indicate that the effect of the crisis was still quite severe, both in Hungary and in other member states, despite there being a steady flow of EU funding during the crisis. Even so, EU funds did help alleviate the negative effects of the crisis in CEE countries. Counterfactual impact evaluations and macro-level approaches show that, without EU funds, the Hungarian GDP growth rate would be even lower (Nyikos, 2013a; Balás, 2015). For example, infrastructure developments could still receive funding, whilst money is still available for SMEs both in the form of grants and financial instruments. The latter was particularly significant given that many banks were reluctant to offer loans at the time. This is contrasted against the current recovery from the crisis, which impacted financial institutions inversely through increasing their willingness to offer loans. Furthermore, economic models have shown that, in beneficiary countries, consumption and wages increase inline with an improvement in productivity. While private investments might be crowded by EU support in the short term, in the medium term increase in productivity becomes significant and investment expenditures grow (Kengyel, 2014: 504).

Administrative capacities and efficient procedures may also have a bearing on whether the impacts of funds are maximised. This is especially important, since member states are responsible for managing programmes, including project selection, control and monitoring (to prevent, realize, and correct any irregularities) and project evaluation (Nyikos \& Talaga, 2015: 116). The literature also highlights the contribution of cohesion policy to economic development, revealing that it is conditional on the capacity of national and regional institutions to design robust strategies, allocate resources effectively, and administer EU funds efficiently (Bachtler et al., 2014: 735). In order to ensure efficient functioning of all implementation systems, it is essential to clearly define powers and responsibilities and establish well-functioning coordination mechanisms, which are well

45 See data in Figure 6. 
documented and properly implemented (Nyikos, 2013a: 52). Weak capacity levels can hamper the effective management and implementation of the Operational Programmes and as a result negatively affect the overall regional development outcomes (Smeriglio et al., 2016: 178). It has also been estimated, through analyses of the absorption of regional funds, that government capacity is positively correlated to ERDF absorption performance (Tosun, 2013: 2). In Hungary, there are sufficient administrative capacities in place to enable adequate implementation of funds. Hungary has also managed to absorb most of the funds available to it in the past two programming periods. On the other hand, the quality of projects may well have had an income on the Hungarian economic data. The literature supports this by pointing out that promoting faster spending through the de-commitment rule has conflicted with the goal of more effective spending through the performance reserve and more targeted spending under the earmarking requirement (Bachtler \& Ferry, 2015: 1270).

In Hungary, the pressure to try to spend all available funds often resulted in the diminishing significance of project-selection quality. This happens towards the end of the programming periods. Yet even so, the Hungarian Government has made plans to commit all available funds for the current programming period before 2019. Looking at the results of this decision, there are uncertainties on whether or not such actions will maximise the positive economic impact of the funds. ${ }^{46}$

\subsection{Methods}

Research methods in this study are twofold: First, we analysed the relevant European and national regulations, literatures, evaluations of the implementation of EU funds in Hungary in the period 2004-2015. This enabled to collect and assess the relevant factors which may influence the results of the use of EU Cohesion Policy funds. In particular, we looked at the issues pertaining to governmental-structure changes and the availability of sufficient administrative capacity in that timeframe, as the regulatory and institutional environment strongly affects the capacity for the efficient and effective use of the funds (Nyikos, 2013). Information collection and validation rely on a range of further sources, including official websites and annual reports, scientific literature, and last, but not least, a great array of interviews with Cohesion Policy experts.

Second, we looked at the figures linked to EU funds to examine its impact on Hungarian economic performance, whether or not outcomes were positive, and how funds were used to offset negative effects of the economic crisis. We assessed the

46 In regions in Hungary competitiveness remained largely unchanged over the 6 years. (Seventh report on economic, social and territorial cohesion) 
relation between the data on absorption and the Hungarian macroeconomic figures to measure the country's performance and identify improvement needs. The research is then expanded into a section explicating the use of financial instruments and how these special types of financing tools function and the challenges that arise from it. By examining significant phenomena linked to the implementation of cohesion sources in Hungary, we find factors that explain the results and issues that need improvement in the future.

\subsection{Results}

Results obtained are interpreted as the causal impact of cohesion policy in Hungary. Our findings confirm that the funds had a positive impact on Hungarian economic performance. However, the Hungarian implementation of the programmes has been difficult and problematic with increasing irregularity levels, not only because of the complexity of cohesion policy regulation, but also because of institutional and regulatory changes in the Hungarian implementation system. Besides the positive macro-economic effect, the funds did not improve productivity, even though they would be essential for long-term convergence.

\subsection{Discussion}

\subsubsection{Implementation of EU Funds: Administration and regulation in Hungary}

Cohesion policy legislation, at both EU and national level, are very complex. Besides the strict and complicated cohesion-policy-legal framework, member states also have to comply with other sets of rules, such as state aid and public procurement. In this complex legal environment, the permanent institutional reorganization significantly increases the risk against proper and regular implementation. Partly, this phenomenon caused government effectiveness to diminish in Hungary the between 1996 and 2015 (Seventh Cohesion Report: 137).

Extant literature suggests that effective use of EU funds depends on member states having sufficient administrative capacity to manage these funds. Undoubtedly, cohesion policy works best in an environment that is supportive of such policy (Nyikos, 2013b: 173). Initially, most Central and Eastern European countries had perceived weaknesses in their legal frameworks, administrative structures, and management systems. However, further attempts have been made to solve these problems through better human resource management, including increased salaries and better career prospects (Bachtler et. al, 2014: 750). In Hungary, it took some time before administrative structures and cohesion policy legislation were developed, only for implementation to be hindered by the continuous institutional and regulatory 
changes taking place. This instability and excessive overregulation not only increased the administrative burden for both beneficiaries and implementing entities, it also complicated overseeing and addressing all ongoing changes that were causing substantially higher compliance risks.

The initial structure of the regulatory framework that Hungary created for the programming period 2004-2006 was rather complex. The domestic regulations not only supplemented the EU regulations, it provided detailed obligations ${ }^{47}$. Managing authorities ${ }^{48}$ retained the right to issue OP and fund-specific rules-each of them adopting their own operational manual. The involvement of multiple agencies ${ }^{49}$ with overlapping authorities created difficulties in maintaining a nationally-consistent approach to the interpretation and employment of regulatory requirements. In the 2007-2013 programming period, a complete overhaul of the system took place. The newly established National Development Agency (NDA) took over the role of managing authorities from all the relevant ministries. The rationale behind this was that national-level objectives could be better realized compared to sectoral objectives, and that the coordination of measures taken under different programs could be improved. Further justification for reorganization revolved around centralization and standardization, where certain tasks such as the operation of IT systems, evaluation, and communication were also centralized within the NDA. Despite the efforts to enhance and cascade shared understanding of the rules throughout a structure comprising more than 25 executing bodies, the overlapping regulations inevitably led to different departures in legal interpretation. Likewise, inconsistency and fragmentation generated an additional compliance burden.

As a result, complete mid-term revision commenced in 2010. This included re-programming and institutional redesign in addition to revisiting the regulatory framework. Coordination and control functions of the managing authorities had to be strengthened and provisions increasing efficiency had to be introduced. The fractured regulatory landscape was replaced by a general overarching government decree $^{50}$ that provided a clearer distribution of tasks between managing authorities and intermediate bodies. It also contained the description of the delivery principles and

47 National rules on the use of EU funds were divided between 5 pieces of legislation, which were supplemented with an Operational Manual containing even more detailed rules on how to implement each process. There was one ministerial decree jointly adopted by 5 different ministries regulating procedural rules. Then there were separate government decrees each regulating one separate area, namely institutions, finance, guarantees and sanctions.

483 ministries (Ministry of Economy, Ministry of Agriculture, Ministry of Employment) and the independent Hungarian Territorial and Regional Development Office

49 The implementation system carrying out the actual transactions was rather fragmented with 22 intermediate bodies.

50 Government Decree 4/2011. (I.28.) on the use of assistance from ERDF, ESF and the Cohesion Fund in the 2007-13 programming period 
governed the functions of project selection, financial implementation and control, management of irregularities and collateral. This regulatory architecture improved consistency and coherence. As a final change towards the end of the programming period, supervision of the NDA was moved from the Ministry for National Development to the Prime Minister's Office.

The start of the 2014-2020 programming period brought with it further substantial changes in the cohesion policy institutional system. From the $1^{\text {st }}$ of January, 2014, the NDA was abolished and its functions were distributed between the pertinent ministries and the Prime Minister's Office. Managing authorities were transferred (back again) to the line ministries. The Prime Minister's Office was also entrusted with the tasks of central coordination ${ }^{51}$. Intermediate bodies were also abolished and their tasks were integrated into the competent ministries carrying out managing authority functions. An exception to this is the Hungarian State Treasury, which acts as an intermediate body for the Territorial and Settlement Development OP.

Driven by the intention to advance efficiency and effectiveness, the government chose to radically recalibrate the programming architecture as well as amend the legislative and institutional environment for the period between 2014-2020. However, the legislative concept remained-namely, to merge all domestic legislative provisions dealing with the system of EU funds implementation into a single government decree. ${ }^{52}$ Notwithstanding, this proved complicated, lengthy ${ }^{53}$, and resulted in 6 annexes $^{54}$. Despite its complex nature, the new decree does provide for some simplifications. The utilization of a simplified project selection method and of grant letters-rather than two-sided grant contracts, which took months to be signed, for relatively straightforward, small-scale projects-was extended significantly.

Thus far, there have been repeated attempts to rationalize the implementation systems and to establish a logical distribution of tasks between institutions. Hungary at last opted for a system, with very strong centralized control, and with a single coordination body and a handful of ministries acting as managing authorities. From this it would seem that adequate administrative capacities exist in Hungary for the implementation of EU funds. However, the continuous reorganizations also resulted

51 The Prime Minister's Office is responsible for member state level coordination tasks, which includes the preparation of programming documents, functions related to programme implementation, monitoring of use of funds, preparation of legislation and proposals for their amendment, and centralised management functions related to programs (e.g. communication, evaluation).

52 Government Decree 272/2014 (XI.5.) on the use of support originating from European Union funds in the 2014-2020 programming period.

53 Its main body contains over 200 sections and its Annex 1 containing the Operation Manual has 388 paragraphs

54 The first of which consists of the Operational Manual. Annex 5 contains a detailed manual on eligible expenditures. The other annexes have provisions on institutions responsible for policies, designation of bodies, document samples and control aspects of supporting documents. 
in negative effects on the system in the form of increased staff turnover and the loss of qualified employees. Salaries of civil servants in Hungary continue to be relatively low compared to the private sector, where the salary base remains unchanged since 2008. Therefore, staff retention is proving to be a challenge for managing authorities. Certain incentives such as performance-related premiums are used to alleviate the problems, but the general sentiment is that more needs to be done.

Table 1: Fluctuation in the Hungarian institution system.

\begin{tabular}{ll}
\hline Year & Fluctuation \\
\hline 2014 & $12.7 \%$ \\
2016 & $14.7 \%$ \\
2017 & $12.6 \%$ \\
\hline
\end{tabular}

Source: Nyikos, data from the KÖZSTAT

Having all relevant provisions in a single piece of legislation is certainly a significant improvement and is projected to make the life of people working in the implementing institutions easier. However, it must be reiterated that the new government decree is not an easy one to apply. Firstly, despite being extensive already, practitioners still insist that the rules do not cover all relevant situations ${ }^{55}$. Furthermore, the decree was adopted in a rush at the beginning of the period, meaning that it constantly had to be adapted to practical issues surfacing during implementation. As a result, it has already been amended 44 times with more amendments expected. While constant amendments can ensure that all legislative problems are resolved, this causes uncertainty in the implementation process, which has the potential to hinder the efficient use of funds. However, the effectiveness of regional policy depends largely on the efficiency of the operation of management organizations and, in general, on the functioning quality of the administrative system as well. Several research (Charron, Lapuente \& Rothstein, 2011; Charron \& Lapuente, 2013; Charron, Dijkstra \& Lapuente, 2014; Nyikos \& Kondor, 2019) and evaluation confirms that the quality of governance and public administration of countries also affects the capacity for the efficient and effective use of the cohesion funds, and in Hungary, there is room for improvement in this area.

55 E.g. the experience of the authors is in particular that the provisions on the use of financial instruments are inadequate 


\subsubsection{Financial Instruments in Hungary}

In the analysis of the effectiveness and the results of the use of cohesion sources in Hungary, and in considering future prospects, it is important to examine the use of financial instruments (FI). Financial instruments have attracted interest because of their revolving character- meaning, FIs invest on a repayable basis, as opposed to grants, which are non-repayable investments ${ }^{56}$. Their use has been promoted because of the added value of revolving instruments compared to that of grants in terms of the efficiency of use of public resources. Secondly, by unlocking other public sector funding and private sector resources through co-financing and co-investment, FIs increase the overall capital available (Nyikos, 2016; Nyikos \& Soós 2018a: 15; 2018b: 18).

Through an examination of the use of FIs, we detect that the credit schemes have over-performed in terms of financial targets. Yet, in the case of guarantee and venture capital schemes, we observe a very slow take up and consequently, slower progress in the allocation of funds. Reasons for the differences in the financial performance indicators are manifold. For instance, slower allocation can be partly institutional and regulative (e.g. time-consuming institutional setup process in the first half of the programming period and perception of regulatory burden when it comes to guarantee schemes), or they can be partly strategic (e.g. higher demand for credit schemes, especially for those combined with non-refundable grants).

In the 2014-2020 period, $60 \%$ of all ESI Funds were dedicated to economic development and job creation. With an allocation of EUR 2.3 billion, Hungary is almost tripling its allocation to financial instruments compared with 2007-2013. Besides SME-development support, the use of FIs has been extended to R\&D\&I, energy, ICT and the social economy. Following a slow start, all loan products and loans combined with grants have been launched, whilst venture capital programs are also under preparation. However, their effectiveness is yet to be determined. There were several changes in the FI implementation.

56 FIs are defined also in Financial Regulation as measures of "financial support provided from the budget in order to address one or more specific policy objectives by way of loans, guarantees, equity or quasi-equity investments or participations, or other risk-bearing instruments, possibly combined with grants". 


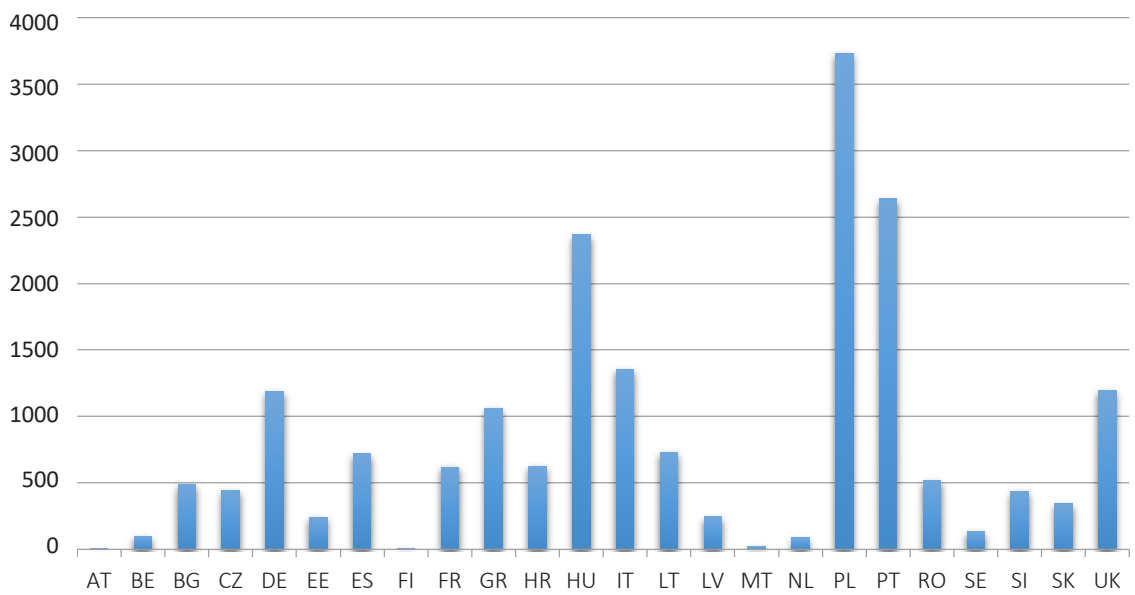

Figure 1: Fls in 2014-2020 period (ESIF in million EUR).

Source: (Nyikos 2016), data from the EC (downloaded on 9. 7. 2016), OPs adopted by EC Hungary implemented Fls in the pre-accession period and, again, in the 2007-2013 programming period when financing was provided in the form of loans, guarantees, and venture capital. According to programme documents and AIR 2013, the main objective of Fls was to overcome the limited access of finance on the market, driven by the assumption that their Fls may represent more efficient forms of SME support than grants.

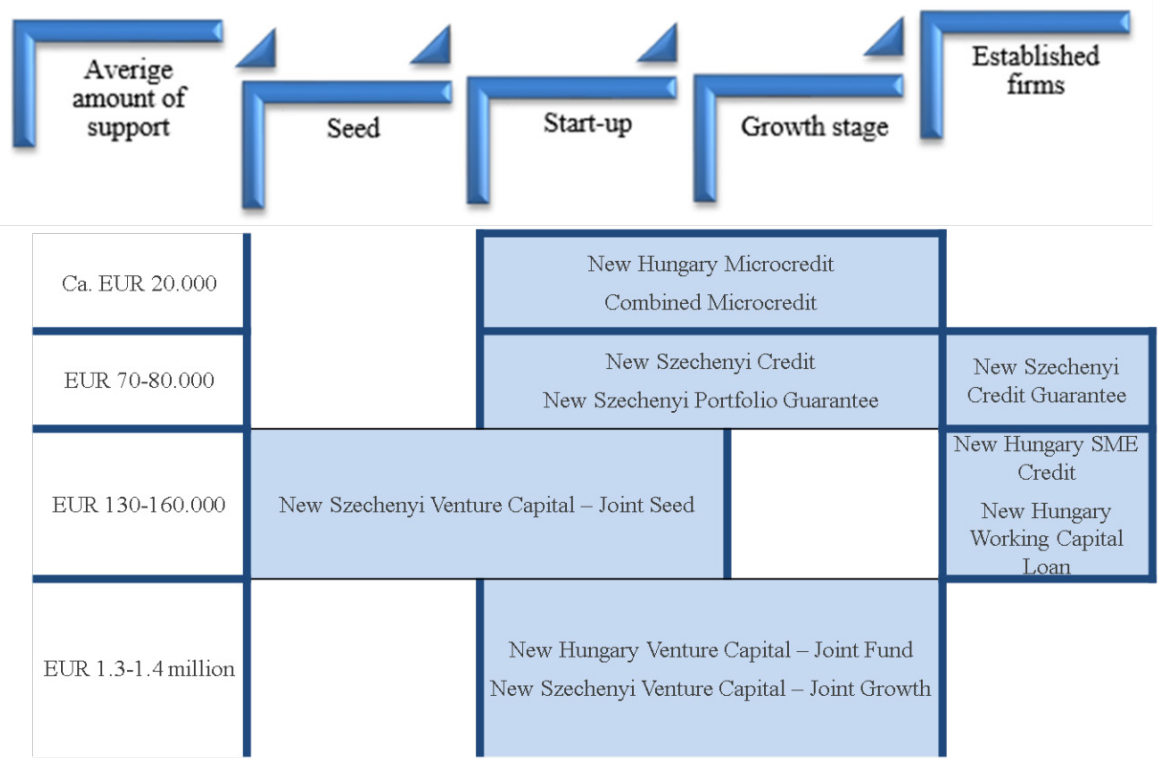

Figure 2: Different Fls in 2007-2013 in the business development cycle.

Source: Nyikos compilation, info from financial agreements and Fontium (2015). 

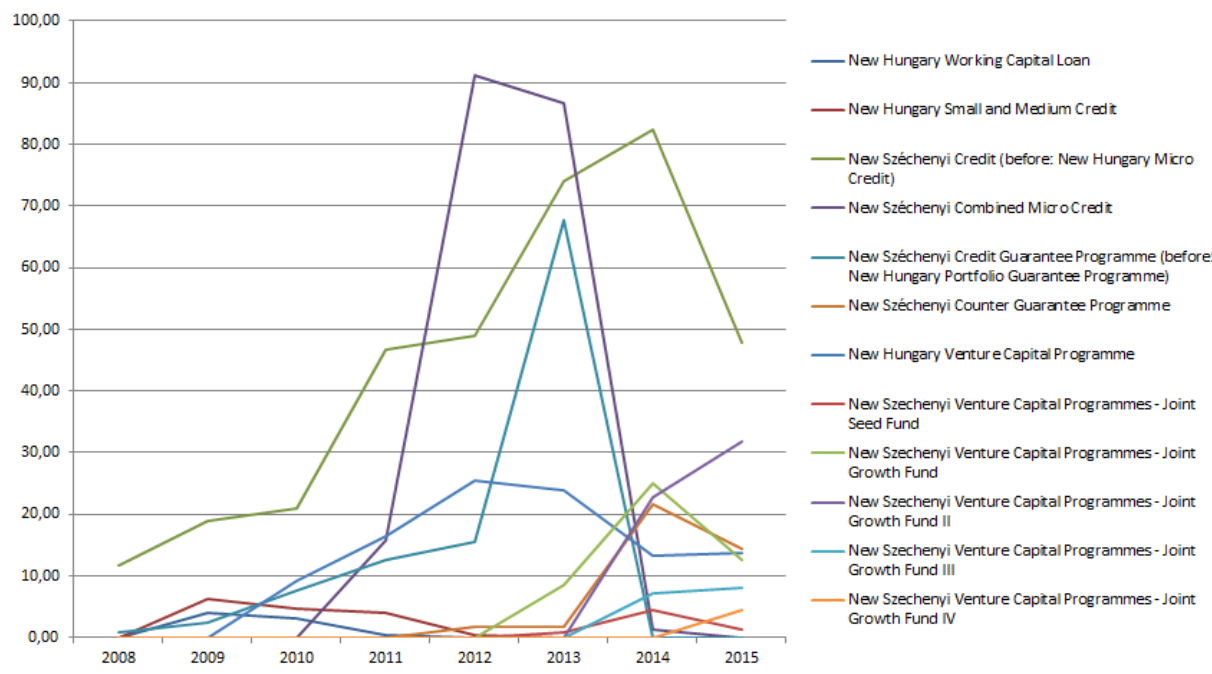

Figure 3: Absorption process of the different Hungarian Fls.

Source: (Nyikos, 2016), data from Hungarian Development Bank

In 2007-2013, Hungary worked with a widespread external intermediary network (credit institutions, financial enterprises, and local enterprise development agencies). In 2014-2020, the financial intermediaries had to be selected through formal public procurement, so a banking consortium as distribution network has been procured. Furthermore, the system based on a re-financing model changed into a distribution system. Likewise, the size of loans increased, as the microfinance model changed to SME finance. This could have been a potential problem with the "number of supported companies" indicator, since it was planned based on previous experience. The use of FIs thus offers more incentives to businesses to use their funds properly and encourage profitable investment. The revolving nature of financial instruments will, as such, allow funds to be re-used in the future.

Table 2: FI loan size in 2007-2013 versus 2014-2020 (in HUF).

\begin{tabular}{llll}
\hline & $\mathbf{2 0 0 7 - 2 0 1 3}$ & $\mathbf{2 0 1 4 - 2 0 2 0}$ & Change \\
\hline Average loan & 16072044 & 91927470 & $572 \%$ \\
Average combined loan & 6450631 & 54729824 & $848 \%$ \\
\hline
\end{tabular}

Source: Nyikos compilation 


\subsubsection{Absorption of EU Funds and Economic Performance}

As suggested in the previous section, Hungary has established its necessary legislative and administrative systems for the use of EU funds, even though challenges, such as maintaining adequate staff levels, remain because of the constant reorganization. Even so, it is necessary to see whether or not the use of EU funds throughout the past programming periods has led to a positively measurable economic performance in the country. Data from all programming periods show that Hungary has had very high allocations of EU funds and has been fairly successful in their use if measured by the percentage absorbed.

Naturally, as Hungary joined the EU in 2004, it did not participate in the 20002006 programming period; it was only allocated a relatively small amount of 2.8 billion euros for the last 3 years of that period. In the next programming period, it received a fairly large amount, i.e. 25.3 billion euros, seizing a lucrative opportunity to boost the economic development of the country. For the 2014-2020 period, it managed to practically maintain the budget it was due to receive from the EU, as its allocation was set at an impressive 25.0 billion euros. Hungary in fact has the second highest allocation of funds per capita. The receipt of such an amount of funding, if used properly, could boost Hungary's GDP growth and other important economic indicators.

According to the relevant data, it seems that Hungary has managed to spend the vast majority of allocated funds in its first programming period. In Hungary, between 2004 and 2008, 95\% of ERDF and EAGGF funds have been paid out while the absorption rate for the ESF was $91.02 \%$ and $86.19 \%$ for the FIFG. Hungary had a total absorption rate of $94.11 \%$ for all the Structural Funds, which was better than both EU25 averages (Bachtler et. al., 2014: 743). Hungary's absorption of funds was similarly quite successful in the 2007-2013 programming period. Not surprisingly, the rate of payments took off quite slowly in 2007, while an increase took place towards, and beyond, the end of the programming period. As a result of the ERDF, ESF and the Cohesion funds, Hungary managed to absorb just over $94 \%$ of available funds-the EU28 average was $94.45 \%$, slightly above the Hungarian absorption rate. 
Absorption of EU Funds in Hungary (\%)

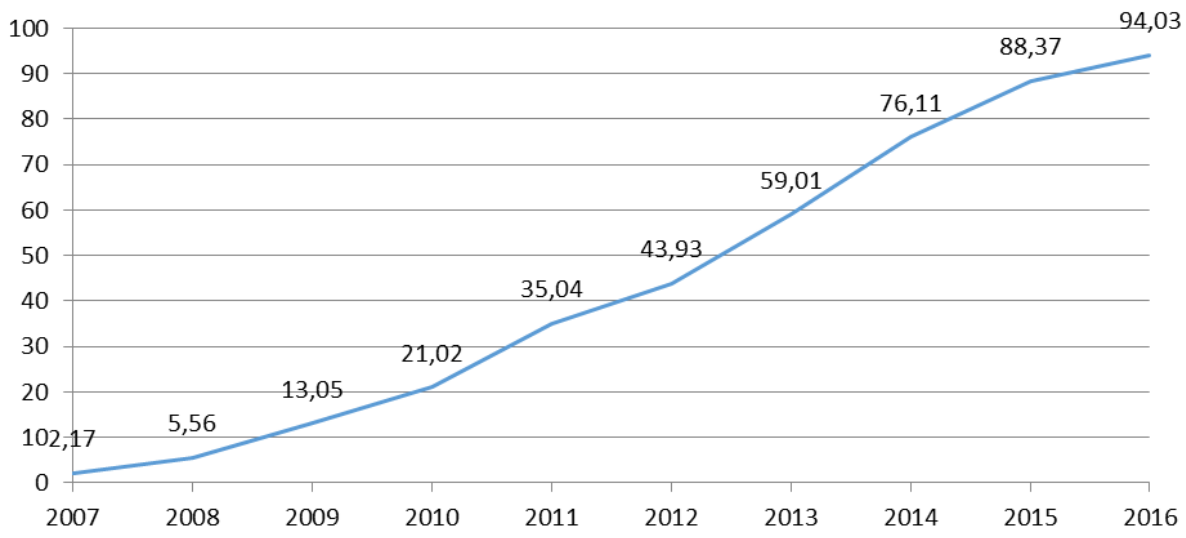

Figure 4: Absorption of ERDF, ESF and CF in Hungary in the 2007-2013 programming period.

Source: European Commission InfoRegio.

If we look at the rate of payments of funds for the EU as a whole, a similar pattern is discerned: that payments were very small in the first few years, before steadily increasing until 2013 (2014 for the EU12) and then dropping slightly in 2015.

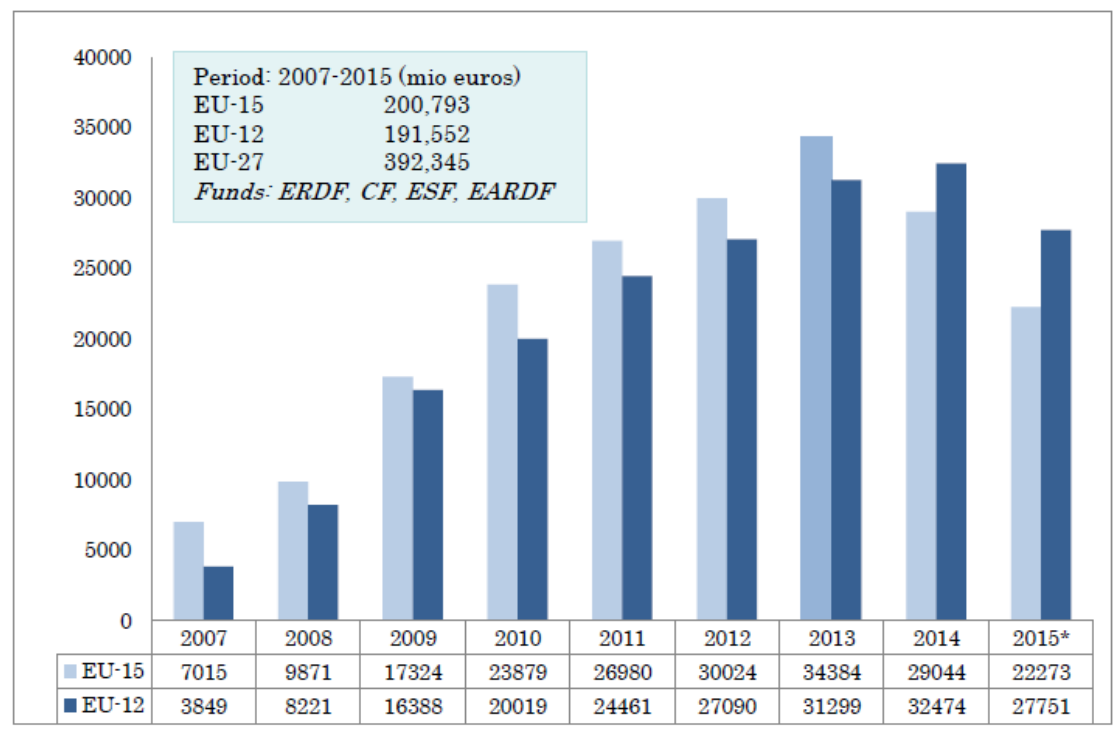

Figure 5: Time pattern of EU payments, all funds (million euros).

Source: EC 2017, referring to: DG REGIO. Totals for ERDF, CF and ESF in 2015 are estimated until endyear; EAFRD payment requests data until August 2015. 
It must be noted that the absorption of the 2007-2013 programming period's transfers in Hungary accelerated after 2009 as illustrated in Figure 6.

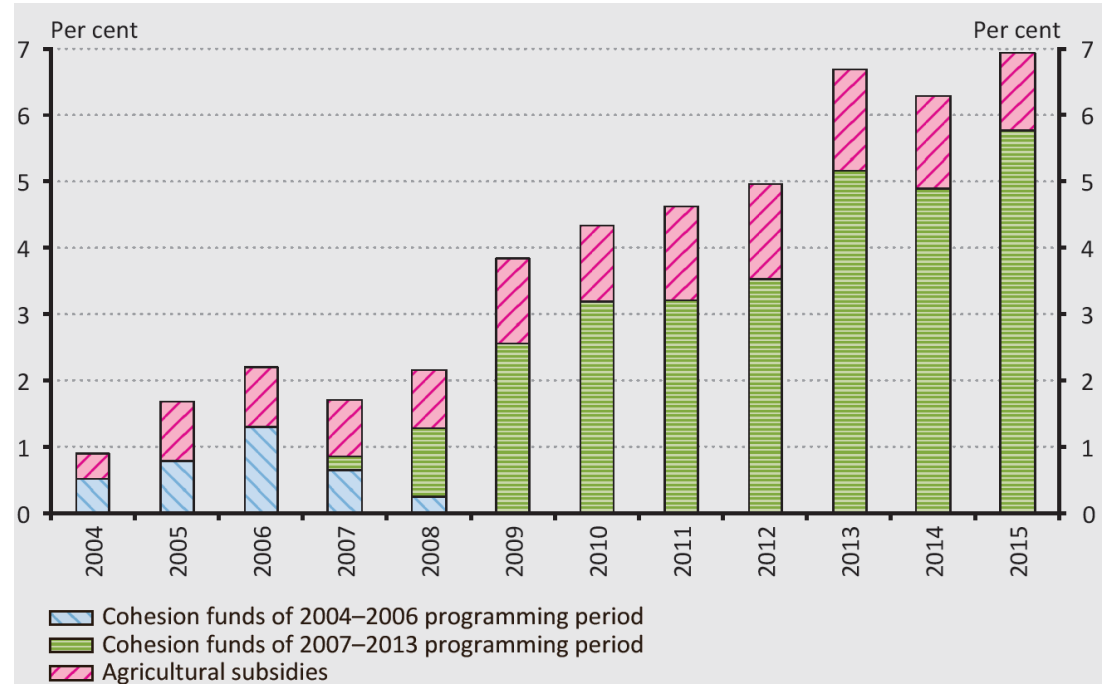

Figure 6: Absorption of the 2007-2013 programming period's transfers in Hungary.

Source: Hungarian National Bank.

There are several possible causes for why absorption has accelerated after 2009. One possibility is that, in 2007 and 2008, the funds of the previous 2004-2006 programming period were typically still being absorbed. Furthermore, it may be caused by the nature of the implementation of multiannual operational programmes and projects (implementation phase after longer preparation) ${ }^{57}$. Another possibility is that after the financial crisis, the state budget's situation stabilized, and due to the SPLs ${ }^{58}$, it was able to provide pre-financing to the beneficiaries. It is also possible that centralisation of implementation (see section 4.1.), as was the integration of MAs into the ministries who worked more closely with the beneficiaries of major projects had a role. Finally, another cause could be attributed to the national cohesion rules on pre-financing expenditures, which have been changed, leading to an increase in possible advance payments. As so, it is too early to make any estimation on whether or not they will achieve the same outcomes in 2014-2020. However, since the programming period is well under way, it is worth looking at how payments are doing in Hungary and how

57 For several programmes, 2007 was a preparatory year, the first calls were launched in 2008 and most of the contracts were signed in 2009.

58 Structural programme loan, see more information: http://www.eib.org/attachments/documents/ mooc_factsheet_eib_loans_en.pdf 
these compare to the total allocations. Examining Table 3 reveals that payments got off on a slow start, comparable to the previous programming period. Unlike the latter, there was a large increase in 2015, while in 2016 the amount of actual payments dropped again. Hungary's payments of EU funds have so far been below the EU average.

Table 3: Total EU cumulative payments in the $2014-2020$ programming period.

\begin{tabular}{llll}
\hline Total EU payments & & & \\
\hline & 2014 & 2015 & 2016 \\
\hline Hungary (million EUR) & 489 & 1879 & 2172 \\
$\%$ of total & 2 & 8 & 9 \\
EU average (\%) & 3 & 9 & 13 \\
\hline
\end{tabular}

Source: European Commission InfoRegio

Examining the fiscal and economic indicators, to determine if any direct correlation can be observed between the use of EU funds and improvements to the Hungarian economy, provides additional information on the usefulness of ESI Funds to support the Hungarian economy. After years of deterioration in Hungary's public finances ${ }^{59}$, spanning the 2011-2016 period, the government has achieved considerable progress in strengthening public finances. Macroeconomic imbalances are being corrected whilst public debt-to-GDP ratio continues to drop. Markedly, the budget deficit decreased in recent years, as did the public-debt ratio, which continued on a declining path. This helped improve financial stability (see Figure 7) ${ }^{60}$. Yet, although financial vulnerabilities have been reduced, non-performing loans still hamper bank lending.

Nevertheless, total investment in Hungary fell following the crisis. Private investment started to decrease in 2008 and its share in GDP has continued to shrink ever since. Public investment has played a stabilizing role, owing to strong EU-funding support. Based on the commitment made by the EU in the 2007-2013 programming period, Hungary was entitled to a funding of EUR 35.3 bn (almost HUF 9,900 bn calculated at EUR/HUF 280, the average exchange rate of the period), accounting for roughly $35 \%$ of the country's annual GDP. The largest part of the allocation came from

59 The effect of electoral considerations in determining budgetary outcomes was evident in Hungary over the last 15 years, with government deficits reaching their highest levels in election years (1994, 1998, 2002 and 2006).

60 Following the outbreak of the financial crisis, the government debt-to-GDP ratio increased sharply, reaching almost $81 \%$ in 2011. Since then, it has decreased by more than 6 pps., falling below $75 \%$ by 2015 . 


\section{A. Public and external deficit}

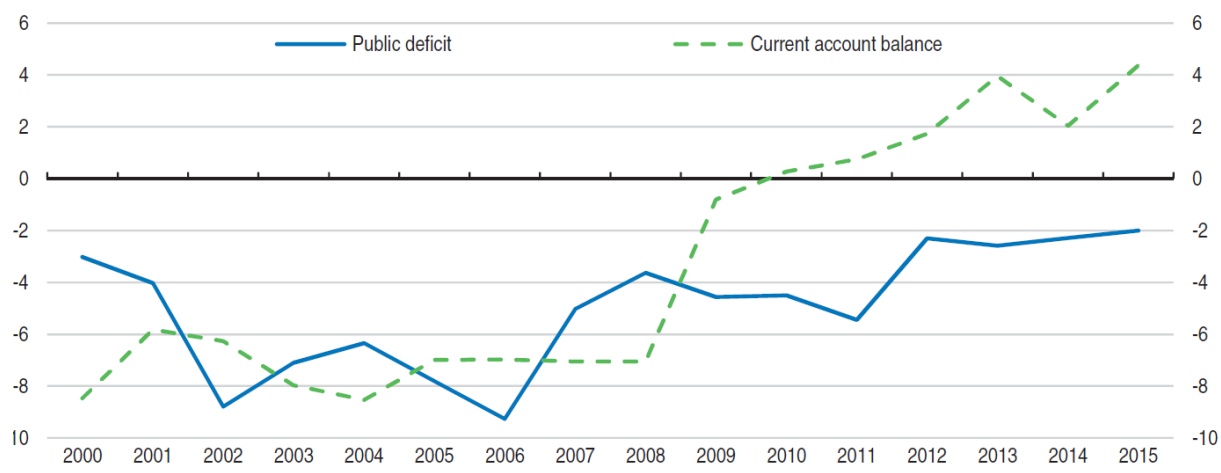

\section{B. Public debt ${ }^{61}$}

90

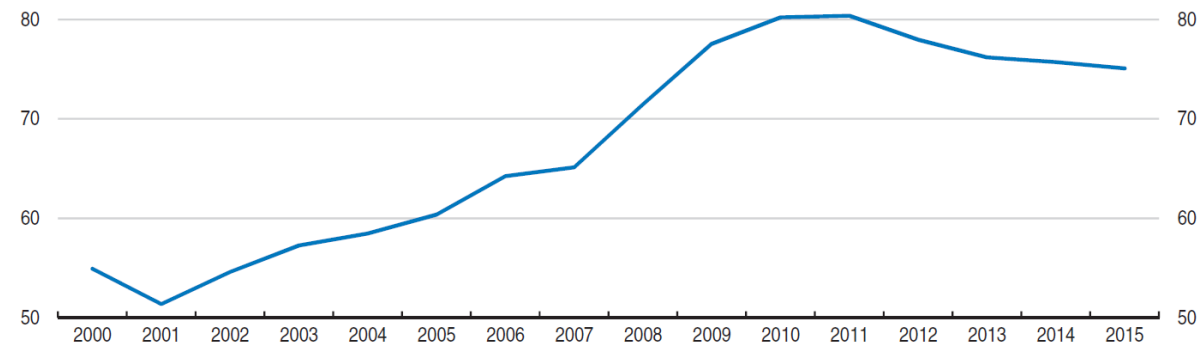

Figure 7: Macroeconomic imbalances are falling (\% of GDP).

Source: OECD (2016), OECD Economic Outlook: Statistics and Projections Database.

the Structural Funds and the Cohesion Fund; these funds amounted to EUR 24.9 bn (HUF 7,000 bn). At the height of the crisis, difficulties in planning large projects and programmes hindered the payments in Hungary, which were further augmented by the need for advanced payments for the beneficiaries. The co-financing obligation must be respected if the cohesion policy funds were to be used, and this became increasingly difficult. Hungary was therefore in need of liquidity, and ostensibly, the cost of the sources became most vital. 


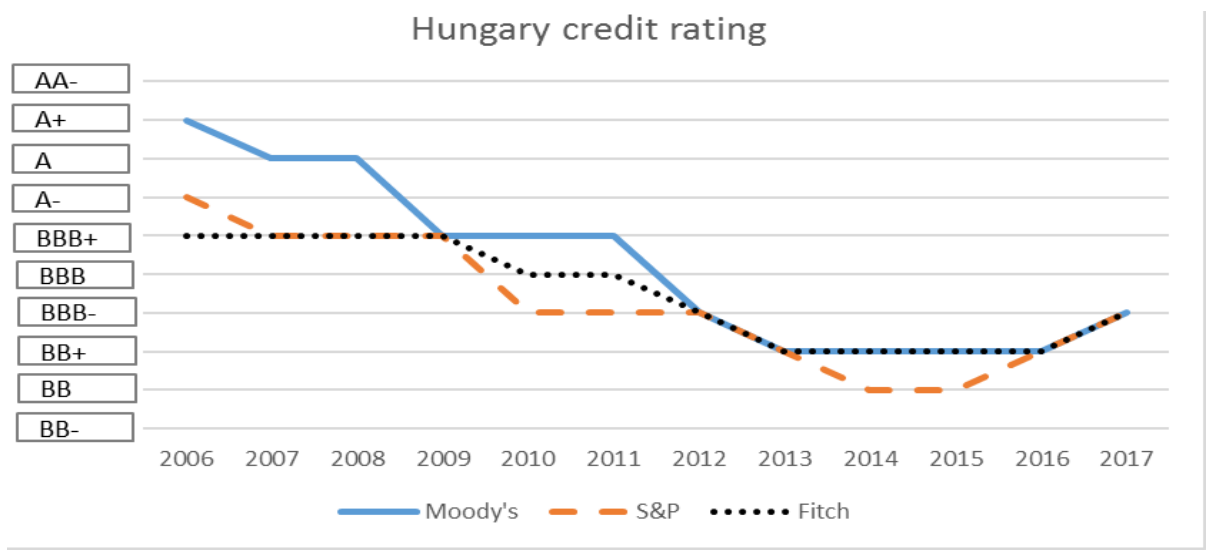

Figure 8. Credit rating of Hungary (2006-2017).

Source: Moody's, S\&P, Fitch.

As such, the EIB's SPLs facilitated a kick-start implementation of the Managing Authority's Operational Programme, setting it on schedule ${ }^{62}$. In the 2014-2020 programming period, Hungary continues to use SPLs for financing the national contribution of ESI Funds as well as the Connecting Europe Facility (CEF).

Table 4: Financial details of the SPLs.

\begin{tabular}{lllll}
\hline OPs & $\begin{array}{l}\text { The Social Renewal OP } \\
\text { co-financed by ESF and } \\
\text { Social Infrastructure OP } \\
\text { co-financed by ERDF }\end{array}$ & $\begin{array}{l}\text { 2007-2013: Transport OP, Environmental and Energy } \\
\text { OP 2014-2020: Integrated Transport Development } \\
\text { (ITOP), Environment and Energy Efficiency (EEEOP) and } \\
\text { Connecting Europe Facility (CEF) }\end{array}$ \\
\hline Source & $\begin{array}{l}\text { EDUCATION CO-FINANCING } \\
\text { FACILITY (HU) (20060511) }\end{array}$ & $\begin{array}{l}\text { COHESION FUND } \\
\text { FRAMEWORK LOAN } \\
\text { (20040589) }\end{array}$ & $\begin{array}{l}\text { COHESION } \\
\text { FUND II } \\
\text { (20100410) }\end{array}$ & $\begin{array}{l}\text { COHESION FUND } \\
\text { FRAMEWORK LOAN } \\
\text { IV (20150006) }\end{array}$ \\
\hline $\begin{array}{l}\text { EU funds } \\
\text { (EUR m) }\end{array}$ & $3,737.79$ & $1,157.27$ & $7,319.00$ & $7,624.00$ \\
$\begin{array}{l}\text { Other funds } \\
\text { (EUR m) }\end{array}$ & 359.61 & 133.81 & $1,048.00$ & 346.00 \\
$\begin{array}{l}\text { EIB funds } \\
\text { (EUR m ) }\end{array}$ & 300.00 & 300.00 & & $1,000.00$ \\
$\begin{array}{l}\text { TOTAL } \\
\text { (EUR m) }\end{array}$ & $4,397.40$ & $1,591.07$ & 770.00 & \\
\hline
\end{tabular}

Source: Nyikos, data from EIB

62 Interview conducted with the Ministry of National Economy. 
Given the magnitude of cohesion policy funding in Hungary, the macroeconomic effects of cohesion funds cannot be ignored. Towards the end of the 2007-2013 programming period, the absorption of EU transfers gradually increased; net grantsreduced by contributions-reached $5-6 \%$ of the GDP. In addition to the accelerating payments, the Hungarian State paid the available total allocation of EUR 24.9 bn in full. In excess of the total allocation, overspending of roughly EUR 1.9 bn also occurred, which may have helped to avoid the loss of funds. Figure 9 shows the significant effect of cohesion policy on both GDP and employment.

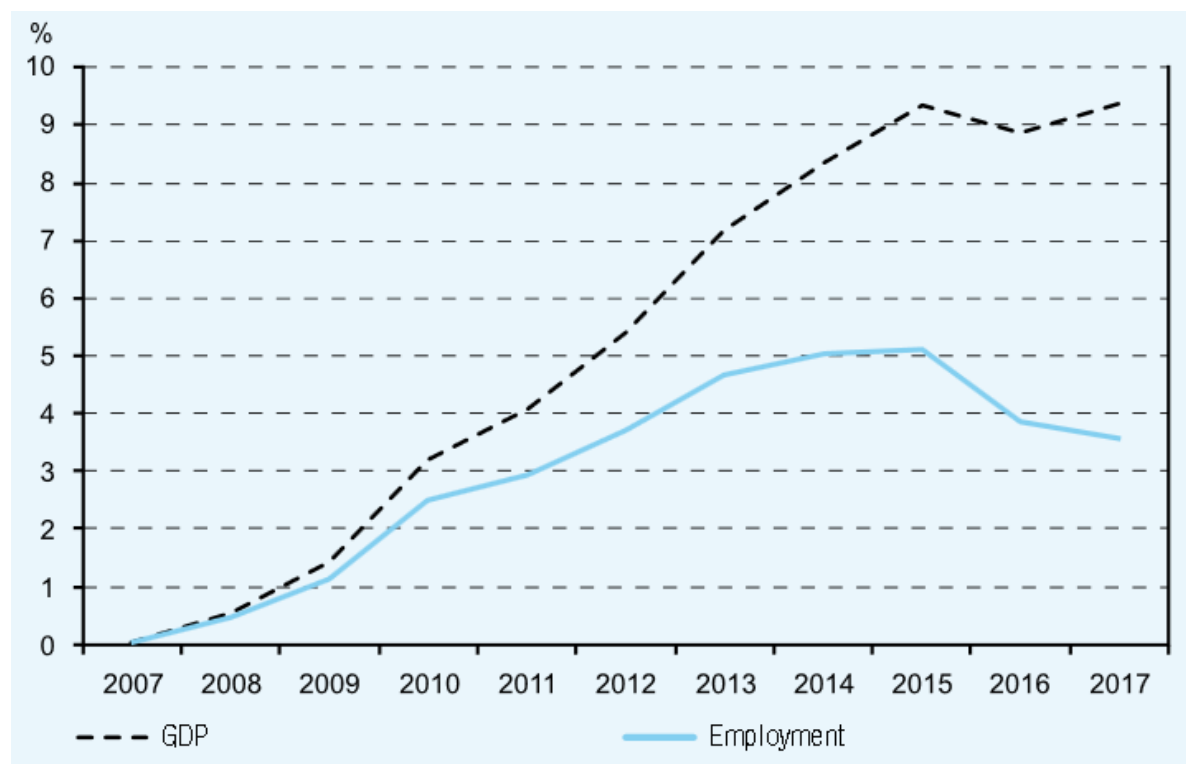

Figure 9: The estimated impact of the national strategic reference framework (2007-2013).

Source: (Nyikos, 2013b), referring to data received from the National Development Agency.

Using a model ${ }^{63}$, the impacts of fund utilisation were compared to a situation without EU development funds. The calculations showed a 5.5\% GDP surplus on a yearly average, compared to a scenario without funding. The simulation also shows that the simultaneous presence of recession, slow growth, and funding, does not necessarily indicate the inefficiency of funding. It is possible that without this funding, the given segment of the economy would be much worse (Nyikos, 2013b).

63 For a detailed description of the model see: http://www.nfu.hu/modellezes 
A study carried out for the European Commission $(2017)^{64}$ shows that cohesion and rural development policies effected many key economic variables of Member States in the 2007-2013 programming period. The study highlighted that interventions substantially increased GDP, in particular in the Members States that are the main beneficiaries of the policies. The highest impact was found in Hungary, where GDP increased by 5.3\% (EC, 2017: 23). In addition, Figure 10 (also published by the European Commission) shows the estimated impact of cohesion and rural development policies on GDP in 2015 and in 2023. Interestingly, it reveals how Hungary is at the top in 2015, but projected to drop by 2023. It is also noteworthy to point that the study highlights a positive impact on real wages, total factor productivity, and private investment.

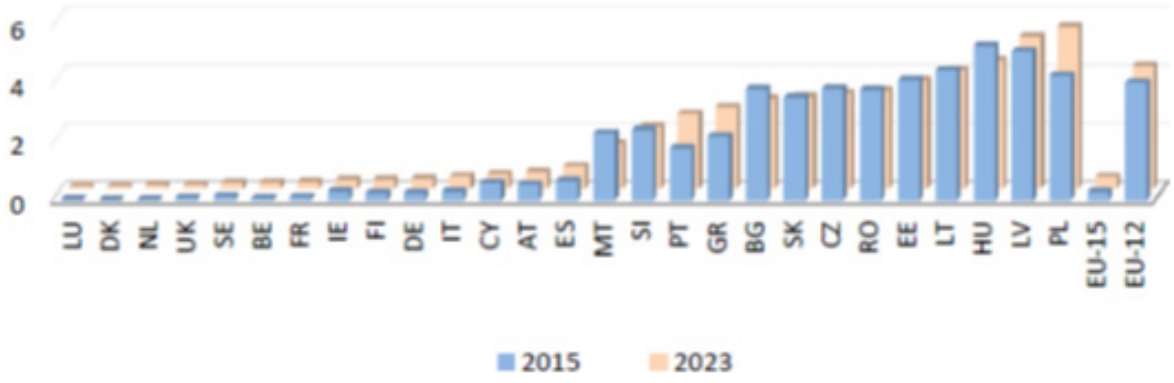

Figure 10: Impacts on GDP of cohesion and rural development policies in Member States, 2015 and 2023 (percentage deviation with respect to baseline).

Source: Commission Staff Working Document Ex post evaluation of the ERDF and Cohesion Fund 2007-13 SWD(2016) 318 final.

With regards to GDP growth, data show that in 2005 and 2006, Hungary had relatively high growth rates of $4.4 \%$ and $3.9 \%$ respectively. However, due to the economic crisis of 2009, GDP growth was badly affected in a similar pattern comparable to the whole EU28. Towards the end of the 2007-2013 programming period, the pace of economic growth picked up significantly, peaking in 2014 and maintaining a relatively strong and stable growth rate in 2015 and 2016.

64 EC Woring Paper WP 05/2017 (2017) The impact of cohesion and rural development policies 20072013: model simulations with quest III 


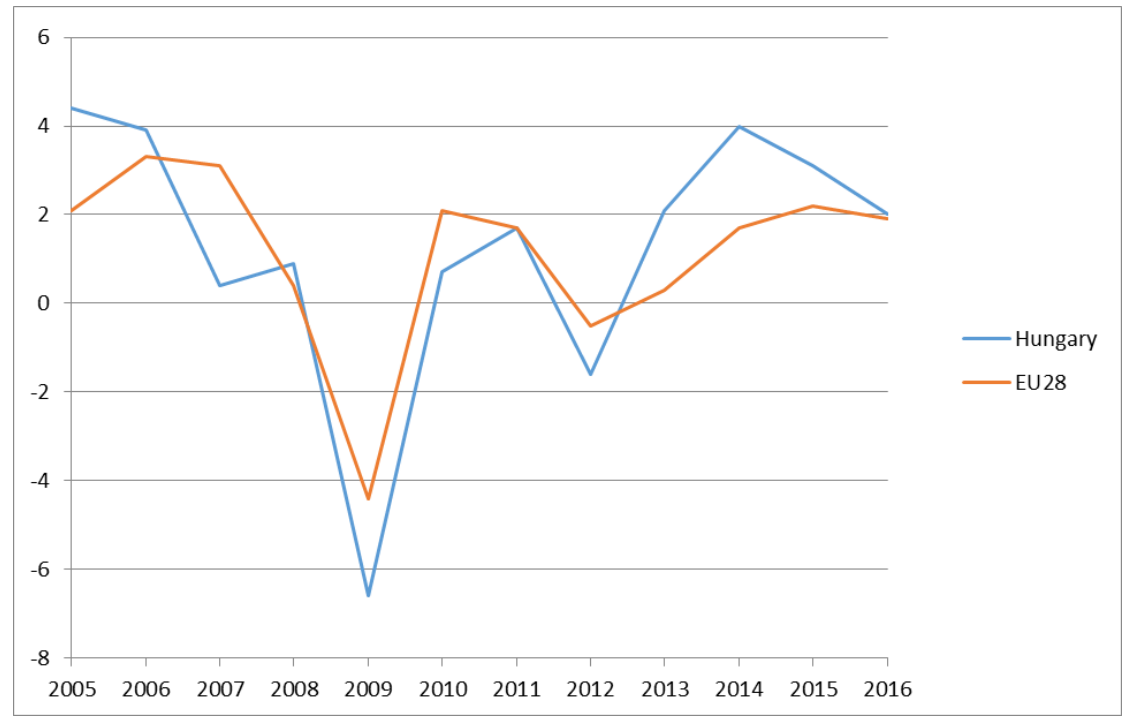

Figure 11: Real GDP Growth rate (\%).

Source: Eurostat.

A similar pattern to GDP growth emerges when examining the employment rates from the data. Unemployment soared as a result of the crisis, and dropped in 2009. Afterwards, the indicator improved significantly towards the mid 2010s, just as the end of the programming period approached.

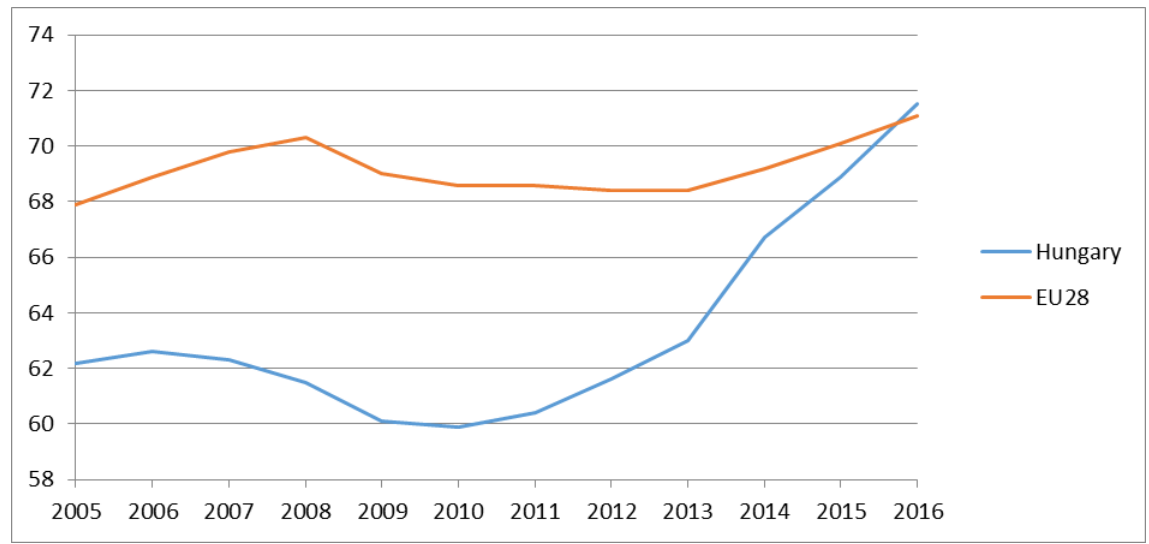

Figure 12: Employment rate (\%) 20 to 64 year olds.

Source: Eurostat. 
Taking into account the effects resulting from the evaluations, and looking at the real figures of GDP growth and employment rates, the data suggest that without EU funds these rates would be much lower. A study carried out by KPMG for the Hungarian government, analysed the impact of funds on the Hungarian economy specifically. The study found that spending on every priority, with the exception of ICTs, has had an impact on GDP, production, consumption, and investments. The biggest impact on GDP was caused by support given to transport infrastructure, while the subsidies provided to farmers had the second largest impact. Also of significance, grants given to enterprises did not have a huge impact on the Hungarian economy, although loans sourced from EU funds had a clear positive impact as illustrated in Figure 13 (KPMG, 2017).

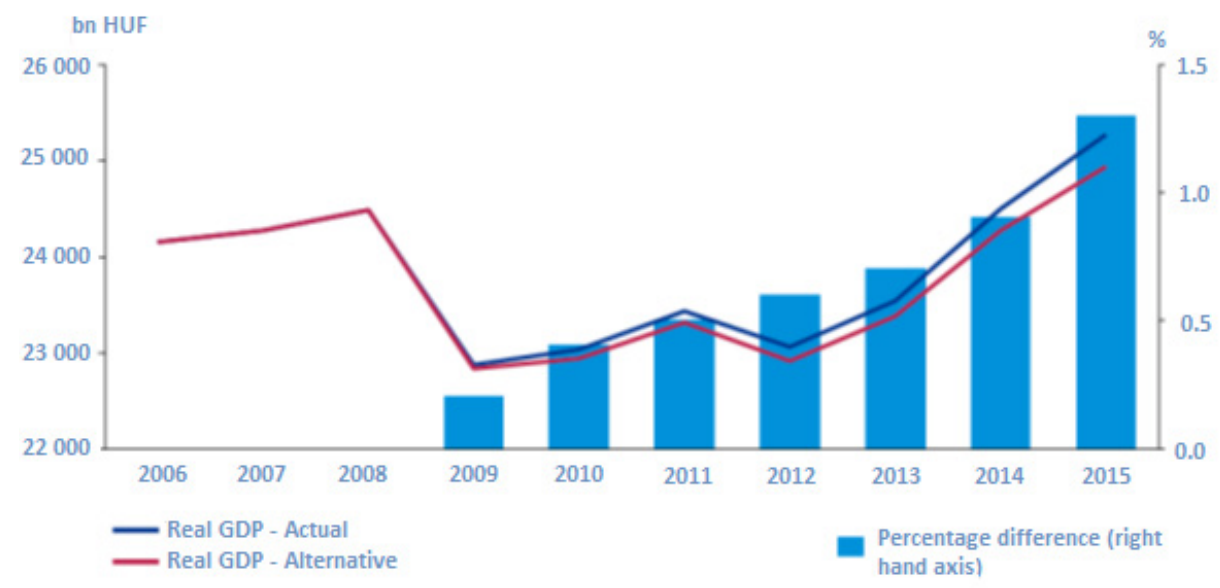

Figure 13: Social Infrastructure: trends in GDP.

Source: KPMG 2017, p. 347 (authors' translation).

It is important to notice that in Hungary without EU funds the state deficit would be always higher than $3 \%$ and the debt instead of reduction would be increased to $84 \%$ of the GDP. The EU funds also helped the fiscal stability with exchange of the Euro to Hungarian forint. 


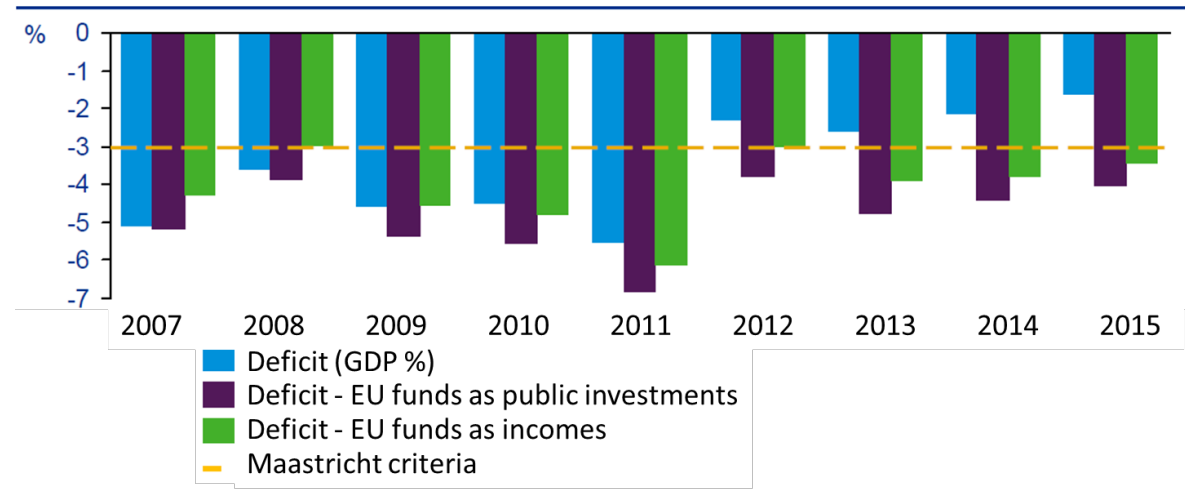

Figure 14: Impact of EU funds on the Hungarian budget.

Source: KPMG 2017.

\subsection{Conclusion}

Following initial difficulties, Hungary managed to develop an administration dealing with EU funds. Fundamental reorganizations have had negative effects on the system. High staff turnover remain a problem. Significant efforts were made to simplify the domestic legislative framework but remain quite complex, needing frequent amendments that ultimately lead to uncertainty. Therefore, more effort is needed to improve certainty and usability of the system.

Coping with the economic crisis has been a huge challenge. During the first half of the programming period, Central and Eastern European countries were trying to recover from the economic downturn. In effect, by looking at patterns in the economic data without substantial analysis, the effects of the use of cohesion policy funds are hardly visible. Some in-depth economic analysis on the other hand, brought to light its impact: without the cohesion sources, the Hungarian economic growth rates would be much lower (Nyikos, 2013b).

For the 2014-2020 programming period, plenty of funds are made available for Hungary. Although a welcomed development, the use of this fairly significant amount, as a financial instrument, is yet to be analysed. Hungary continues to have a very large amount to spend, which, if used effectively, can no doubt revitalize the economy and increase productivity. This will, however, depend on a number of factors: Maintaining and improving administrative capacities is a key factor. Reiterating from previous sections, there is a strong correlation between administrative capacities and the effectiveness of EU funds. Hungary has a functioning institutional setup. However, there is a risk that after general elections-even though the former governing party won-reorganization of the government and institutional changes will follow. It 
will thus be essential to have some stability in the implementation system and even increase the level and quality of human resources through proper training and reduction of staff turnover.

As indicated by some authors, for the post-2013 period, very strict rules were put in place for the use of cohesion policy funds with ex-ante and ex-post conditionalities, milestones, strict payment conditions, and a performance reserve (Nyikos, 2013a: 42). Legislation at both EU and national level remains very complex. Besides the strict and complicated cohesion policy, legal framework member states also have to comply with other sets of rules, such as state aid and public procurement. Noncompliance can lead to financial corrections and obligation to repay state aid. Therefore, focusing on simplification will be essential for the administration to be able to cope with the legislative framework and be able to strike the right balance between following the rules, effective and efficient selection, and implementation of projects.

Success will also depend, to an extent, on the approach of the Government towards the use of funds. If at any stage of implementation there is pressure to use as much of the funds as possible in a relatively short time, then there is a threat to the quality of projects. So far, the quick disbursement of the funds seems to be a high priority. Unfortunately, there are issues with this in terms of what effect it will have on quality. In addition, it will be important for the implementation process to be free from all sorts of corruption. Selection of beneficiaries on the basis of personal connections and deliberate overestimation of certain expenditures should be avoided.

It is also likely that the use of financial instruments will be the norm rather than the exception in the next programming period. This means that Hungary should gain as much experience as possible in the use of financial instruments to draw the necessary conclusions. Making more use of the potential-leverage effect of financial instruments will ensure higher levels of economic development. In any case, early preparation for the next programming period is key for success. Hungary should prepare its administration as early as possible for the new legislative framework. Its experience in using financial instruments will be critical for the upcoming era.

\section{References}

Bachtler J. and Ferry M. (2015) Conditionalities and the Performance of European Structural Funds: A Principal-Agent Analysis of Control Mechanisms in European Union cohesion policy. Regional Studies, 49:8, 1258-1273

Bachtler J., Mendez C. and Oraze H. (2014) From Conditionality to Europeanization in Central and Eastern Europe: Administrative Performance and Capacity in cohesion policy. European Planning Studies, Vol. 22, No. 4, 735-757 
Balas, G., A. Csite, G. Kiss, K. Major, N. Németh and A. Piross (2015), Az EU-források gazdaságfejlesztési és növekedési hatásai, tech. rep., HÉTFA Kutatóintézet

Borsi M.T. and Metiu N. (2013) The evolution of economic convergence in the European Union. Discussion Paper Deutsche Bundesbank No 28/2013

Camagni R. and Capello R. (2014) Rationale and Design of EU Cohesion Policies in a Period of Crisis with special reference to CEECs, Policy Paper No. 1, GRINCOH Working Paper Series

Cappelen, A., F. Castellacci, J. Fagerberg and B. Verspagen (2003), 'The impact of EU regional support on growth and convergence in the European Union', JCMS: Journal of Common Market Studies, vol. 41 no. 4, pp. 621-644

Charron, N., \& Lapuente, V.(2013), 'Why do some regions in Europe have a higher quality of government?', The Journal of Politics, 75(3), 2013, 567-582.

Charron, N., Dijkstra, L., \& Lapuente, V. (2014), 'Regional governance matters: quality of government within European Union member states', Regional Studies, 48(1), 2014, 68-90.

Charron, N., Victor Lapuente, V., \& Rothstein, B. (2011), 'Measuring Quality of Government and Sub-national Variation', Report for the EU Commission of Regional Development, European Commission Directorate-General Regional Policy Directorate Policy Development, 2011.

Commission Staff Working Document Ex post evaluation of the ERDF and Cohesion Fund 2007-13 SWD(2016) 318 final

EC Woring Paper WP 05/2017 (2017) The impact of cohesion and rural development policies 2007 2013: model simulations with quest III

EUROPEAN COMMISSION, Investing in jobs and growth - maximising the contribution of European Structural and Investment Funds, COM(2015)639final, 14.12.2015, Bruxelles 2016

Kengyel Á. (2014) Az európai uniós tagság, mint modernizációs hajtóerő. Gondolatok a kelet-középeurópai országok EU-tagságának 10. évfordulóján. Közgazdasági Szemle, LXI. évf. április 493-508. o.

KPMG (2017) A magyarországi európai uniós források felhasználásának és hatásainak elemzése a 2007-2013-as programozási időszak vonatkozásában

Nyikos G. (2013a) Kohéziós intézményrendszerek - tapasztalatok és kihívások. Pro Publico Bono Magyar Közigazgatás. Issue 2013/3.

Nyikos G. (2013b) The Impact of Developments Implemented from Public Finances, with Special Regard to EU cohesion policy. Public Finance Quarterly 58.2, 163-183.

Nyikos G. and Talaga R. (2015) Cohesion policy in Transition. Comparative Aspects OF THE Polish And Hungarian Systems of Implementation. Comparative Law Review, 18, 111-139.

Nyikos G. (2016): Research for REGI Committee - Financial instruments in the 2014-20 programming period: First experiences of Member States, European Union, 2016

Nyikos G. (2017) Kohéziós Politika 2014-2020. Az EU belső fejlesztéspolitikája a jelen programozási időszakban. Dialóg Campus kiadó, Budapest

Nyikos, G; Kondor, Zs. (2019), The Hungarian Experiences with Handling Irregularities in the Use of EU Funds; Nispacee Journal of Public Administration and Policy XII : 1 pp. 113-134., doi. org/10.2478/nispa-2019-0005

Nyikos, G; Soós, G (2018a) Microfinance and access to finance of SMES In: Ondřej, Dvouletý; Martin, Lukeš; Jan, Mísař (szerk.) Proceedings of the 6th International Conference Innovation Management, Entrepreneurship and Sustainability: Wirtschaftsuniversität VŠE Prag, (2018) pp. 831-845.

Nyikos, G; Soós, G (2018b), Financial Instruments in EU Cohesion Policy and Public Procurement: Challenges for the 2014-2020 Programming Period Public Procurement Law Review 2018 : 32 pp. 120-137.

Pereira, A. and V. Gaspar (1999), 'An Intertemporal Analysis of Development Policies in the EU', Journal of Policy Modeling, vol. 21 no. 7, pp. 799-822 
Smeriglio A., Bachtler J. and Sliwowski P. (2016) Administrative capacity and cohesion policy: new methodological insights from Italy and Poland. In: Learning from Implementation and Evaluation of the EU cohesion policy. RSA Research Network on cohesion policy, pp. 173-190. Tosun J. (2013) Absorption of Regional Funds: A Comparative Analysis. JCMS 2013 pp. 1-17 